\title{
METHODS IN MAKING STEEL-COPPER SANDWICH LAMINATES MATERIALS
}

\author{
Arianto Leman Soemowidagdo ${ }^{1}$, Tiwan ${ }^{1}$ \\ ${ }^{1}$ Jurusan Pendidikan Teknik Mesin FT UNY \\ Email: arianto_ls@uny.ac.id
}

\begin{abstract}
This research is aimed at developing a methods to make steel-copper sandwich laminate materials. The research focused on the method in developing the sandwich material. In method I, the steel plate arrangement is heated up to austenite temperature and subsequently a molten copper is poured into it. In method II, the steel plate arrangement is immersed into a molten copper in a temperature of $1200^{\circ} \mathrm{C}$. The result shows that in method I, the diffusion on the interface layer of steel-copper sandwich laminate is unemployed because of an occurrence of oxidation on the steel surface. On the contrary, in method II the diffusion on the interface of steel-copper sandwich laminate is indicated by a higher shear stress, which is $231.88 \mathrm{~N} / \mathrm{mm}^{2}$. However, the immersing method need to be improved to give better products, since cavities caused by trapped air still exist and are reducing the quality of the laminates.
\end{abstract}

Keywords: production method, steel, copper, composite, laminate material

\begin{abstract}
ABSTRAK
Penelitian ini ditujukan untuk mengembangkan metode pembuatan laminat baja-tembaga. Penelitian difokuskan pada metode pembuatan laminat. Pada metode I, susunan pelat baja dipanaskan hingga suhu austenit dan kemudian tembaga cair dituangkan. Metode II adalah merendam susunan pelat baja ke dalam tembaga cair bersuhu $1200{ }^{\circ} \mathrm{C}$. Hasil penelitian menunjukkan bahwa pada metode I tidak terjadi difusi pada lapisan antarmuka laminat baja-tembaga karena permukaan baja mengalami oksidasi saat dipanaskan. Sebaliknya, metode II menunjukkan terjadi difusi pada antarmuka laminat baja-tembaga dengan tegangan geser tertinggi $231,88 \mathrm{~N} / \mathrm{mm}^{2}$. Namun, metode II harus diperbaiki untuk memberikan produk yang lebih baik karena masih terdapat rongga akibat udara yang terjebak dan mengurangi kualitas laminat.
\end{abstract}

Kata kunci: Metode pembuatan, baja, tembaga, bahan laminat

\section{INTRODUCTION}

Sandwich material is a composite that designed laminately between two or more material. The purpose in building up this material is to improve the characteristics of material such as strength, toughness, wear resistance, ductility and so on. Generally, this sandwich was arranged from hard-strong material at the outside and light-ductile material inside. Table 1 shows several methods that have been used to make a sandwich.

Table 1. Sandwich material making method

\begin{tabular}{lll}
\hline Sandwich material & Making method & Reference \\
\hline Metal-resin-metal sandwich & Hot Pressing & Nagai et al., 1986 \\
Sandwich material & Honeycomb core & Pflug and Vangrimde, 2003 \\
Sandwich material & Fibrous core & Clyne and Markaki, 2004 \\
Multi-layer metal sandwich materials & Epoxy-based adhesive system & Garnault et al., 2004 \\
Metallic Sandwich Sheet & Diffusion bonding & Bouaziz et al., 2006 \\
Composite metal sheet & Roll bonding & Groll, 2008 \\
CrNi steel - Ti sandwich material & Explosive cladding & Ostroushko and Mazancová, 2010 \\
Steel - nickel laminate & Forging & Cahyono, 2010 \\
\hline
\end{tabular}


Table 2. Low Carbon Steel Chemical Composition

\begin{tabular}{cccccccccc}
\hline Element & $\mathrm{Fe}$ & $\mathrm{C}$ & $\mathrm{Si}$ & $\mathrm{Mn}$ & $\mathrm{P}$ & $\mathrm{S}$ & $\mathrm{Ni}$ & $\mathrm{Cr}$ \\
\hline Composition (\% weight) & 99.576 & 0.033 & 0.008 & 0.236 & 0.015 & 0.012 & 0.016 & 0.014 \\
\hline & \multicolumn{1}{c}{} & & & & & & \\
\hline Element & $\mathrm{Pb}$ & $\mathrm{Cu}$ & $\mathrm{Sb}$ & $\mathrm{V}$ & $\mathrm{Ti}$ & $\mathrm{Co}$ & $\mathrm{Al}$ \\
\hline Composition (\% weight) & 0.003 & 0.007 & 0.002 & 0.001 & 0.002 & 0.002 & 0.004 \\
\hline
\end{tabular}

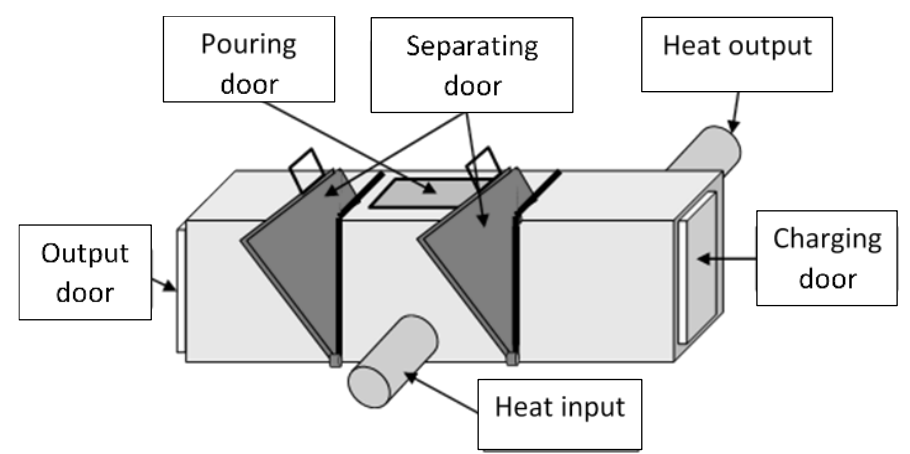

Figure 1. Heating chamber

Cahyono (2010) had adopted the making of keris (an indonesian traditional weapon) to make steel-nickel laminate. It was found that steel-nickel laminate quality getting better when the laminate number increased. However, heating up while it is forged caused an oxidation that generate slag and this slag inhibit diffusion bond occur thus reducing the quality of the product.

A method in making sandwich laminate material is also noted in the holy Qur' an (QS 18: 96). It is explained that steel is heated up until turns to red and then a molten copper poured on it. Steel which turns into red indicates that it is in austenitic zone. If molten copper poured into that steel, the diffusion bond between steel and copper will take place. An experimental study has been performed to develop a sandwich laminate material of steel-copper. The basic concept developed is combining the heated steel and liquid copper to make the corresponding sandwich. The diffusion bond between steel and copper shows that this method works and the quality is then charactirized.

\section{METHOD}

A low carbon steel plate of $4 \mathrm{~mm}$ thick is used. It is arranged with gap between plates of
$4 \mathrm{~mm}$ so that there will be 5 layers. They are then combined by tack weld. The chemical composition of low carbon steel plate used in this research are shown in Table 2.

The method I is pouring a molten copper on the steel which in austenitic zone and the method II is immersing the steel into molten copper. In the method I, combined steel plate of $200 \mathrm{~mm} \times 300 \mathrm{~mm}$ is heated in a heating chamber as shown in Figure 1. It consists of three chambers, which are initial heating, pouring and cooling chambers that each is separated by a door. The heat is put it in to pouring chamber and then flow through initial heating chamber. The steel is heated up to $800{ }^{\circ} \mathrm{C}$ and then molten copper of $1200{ }^{\circ} \mathrm{C}$ poured. The copper will fill in the gap in steel arrangement.

In the method II, the $60 \mathrm{~mm} \times 60 \mathrm{~mm}$ arranged steel plate is immersed into molten copper of $1200{ }^{\circ} \mathrm{C}$. As it immersed, the steel temperature will be raised up into austenitic zone and the copper liquid will fill the gap in that steel arrangement.

The sandwich laminates resulted from these two methods then examined. Oxidation is determined physically while the diffusion is examined through micro structure investigation. The Olympus microscope is used to reveal the diffusion. Shear test is conducted to determine 
bonding strength between steel and copper interface layer.

\section{RESULT AND DISCUSSION}

In the method I, copper is melted in crucible furnace. The copper is put in a crucible steel pot of $130 \mathrm{~mm}$ diameter and $150 \mathrm{~mm}$ height. It has three hooks to pick up from the furnace and to pour the copper. Five percent weight of brass is added in order to enhance copper flow ability. As the temperature of steel reached up to $800{ }^{\circ} \mathrm{C}$, the copper is poured on it. The result shows that diffusion is not occur in the laminate layer between steel and copper as shown in figure 2 . The oxidation appeared on the steel surface since it is heated in an atmospheric environment. The heated steel is then directly contact with atmospheric air containing oxygen. The oxidation reaction on this steel surface is difficult to avoid. This is similar with experiment conducted by Cahyono (2010).

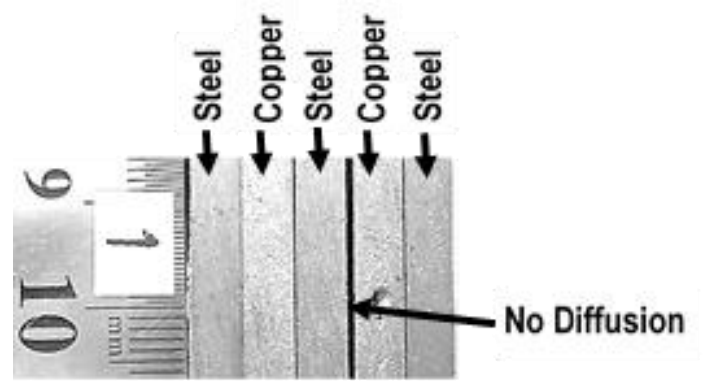

Figure 2. Showing no diffusion between steel and copper

This method could not be implemented unless the steel is heated in the vacuum chamber. Another possibility is by putting another material on the steel surface so that oxidation retarded. However, this should need further investigation to determine the suitable material.

As in the previous method, in method II, copper is melted in the crucible furnace but it is melted in the bigger crucible pot which has dimension $230 \mathrm{~mm}$ of diameter and $220 \mathrm{~mm}$ height. The slag that raised on the top of liquid copper should be cleaned before the steel immersed. Similar as previous method, five percent weight of brass was added to the copper. The steel was then immersed in the liquid copper of $1200{ }^{\circ} \mathrm{C}$ for about two minutes as shown in Figure 3. It is done to make sure that steel reached the austenitic temperature and also gives enough time for copper to fill the gap in the steel arrangement. Figure 4 shows that there is diffusion on interface layer between steel and copper.

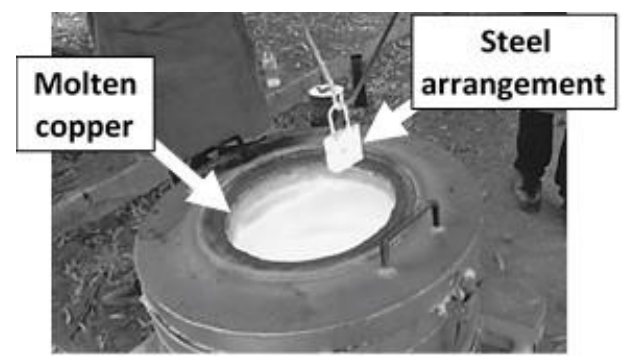

Figure 3. Steel after immersed in molten copper

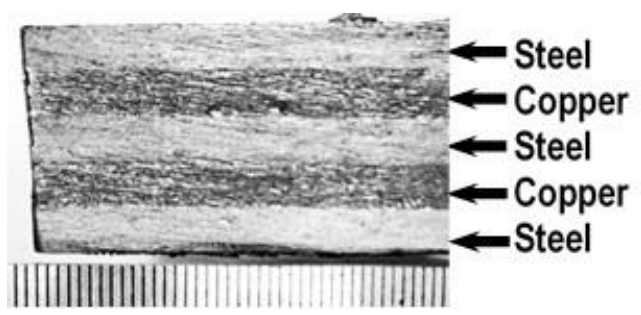

Figure 4. Steel-copper laminate

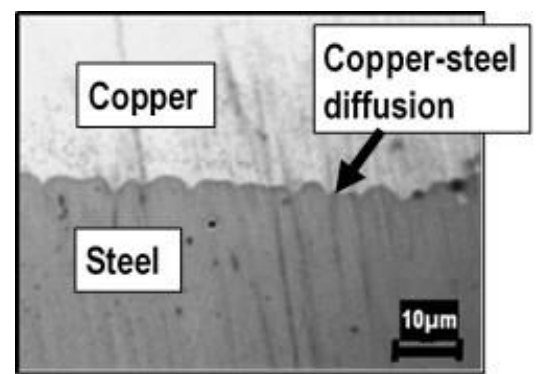

Figure 5. Diffusion of copper and steel

Figure 5 shows further observation using microscope. Figure 5 indicate that there is a bond between steel and copper. Few small void was observed in the copper. It could be caused by a trapped gas when steel was immersed. This also could be caused by a slag that occured on the steel surface or in the liquid copper during immersing. This should be investigated deeper. 
The microstructures in Figure 6 shows a thin layer in the diffusion zone. The composition of this layer is not revealed since EDAX examination not conducted. However, the examination on steel chemical composition as shown in Table 1, indicate that beside Fe and $\mathrm{C}$, there are other elements. Furthermore, brass which is alloy of copper and zinc was added to copper and melted together. All of these elements could be play an important role and affecting to the diffusion process.

It is clear in Figure. 4 that steel and copper were bonded together and diffusion took place. However, cavity do exist inside the material as shown in Figure 7. The air in the gap of arranged steel could not flow out while the steel was immersed. The cavity shape is bigger at the top side because the trapped air could not pass the molten copper which has high viscosity. This shape explains that while immersed, air in the gap slowly move to the top side but the molten copper at the top side solidifies more quickly, thus cavity arise. This phenomenon also shown in the shear test result in Figure 8. The rounded cavity shape and relatively smooth of cavity surface indicated that air in the gap does not have enough time to flow out from molten copper. It is suggested from this observation result that the arranged

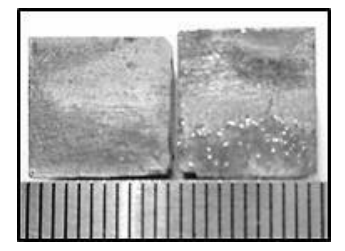

Laminate 1-2

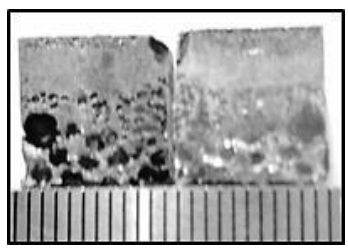

Laminate 2-3

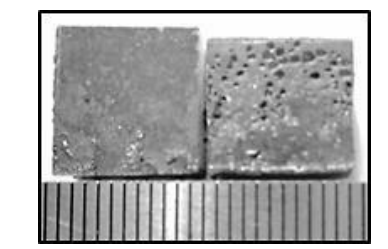

Laminate 3-4

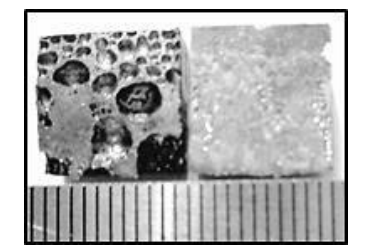

Laminae 4-5

Figure 8. Shear fracture of specimen A

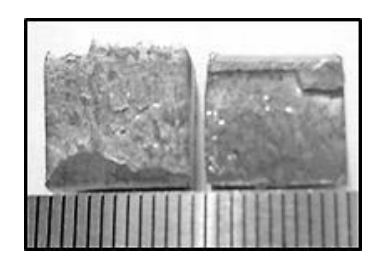

Laminate 1-2

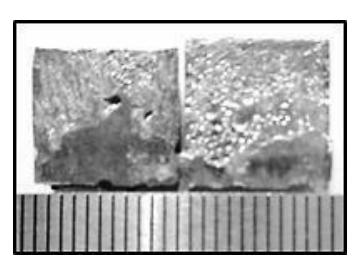

Laminate 2-3

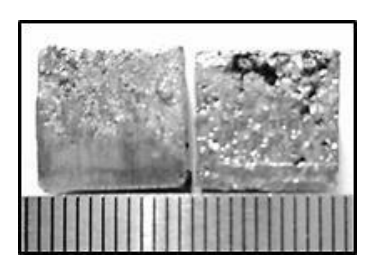

Laminate 3-4

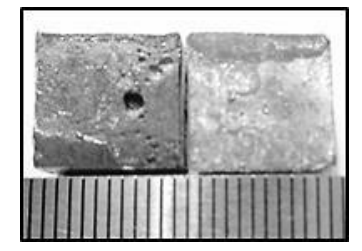

Laminate 4-5

Figure 9. Shear fracture of specimen B 
Table 3. Shear stress between layers

\begin{tabular}{ccccc}
\hline \multirow{2}{*}{ Specimen } & \multicolumn{5}{c}{ Shear stress between layer $\left(\mathrm{N} / \mathrm{mm}^{2}\right)$} \\
\cline { 2 - 5 } & $1-2$ & $2-3$ & $3-4$ & $4-5$ \\
\hline A & 72.46 & 76.09 & 18.12 & 90.58 \\
B & 231.88 & 101.45 & 181.16 & 169.57 \\
\hline
\end{tabular}

Table 3 indicate that the shear stress of specimen $\mathrm{A}$ is lower than specimen $\mathrm{B}$. Moreover, in the layer 3-4 of specimen A is only $18.12 \mathrm{~N} / \mathrm{mm}^{2}$. Figure 8 shows how this could happen. Observation in specimen A was found that cavities on copper side were caused by trapped air. These cavities decrease the contact area within layer which reducing shear stress. The oxygen in the cavities also generate oxidation on steel surface. These two reasons explain how the shear stress of specimen A is lower.

On the contrary, figure 9 shows that shear fracture of specimen $b$ does not occur at the steel-copper layer but it takes place on copper side. It is clear from fracture shape that is not flat. Copper is a ductile material that gives fibrous fracture surface. However, the copper strength is lower than steel, so fracture occurs on copper. This also indicates that layer bonding strength is higher than copper strength. This proves that diffusion reaction is generated between steel, copper and other elements contained in steel or copper.

The differences behavior of specimen A and $B$ shows that this second method should be improved in order to obtain consistent product. This can be done by modification of arrangement of steel plate to avoid trapped air. However, immersing method is rather difficult to produce a bigger component. Another method should be developed to improve the process to make steelcopper sandwich laminate. Several experiments should be done to gain better process, result and usefulness of this sandwich.

\section{CONCLUSION}

Two method to make sandwich material of steel-copper have investigated. The method I is pouring molten copper into heated steel and the method II is immersing steel into molten coper. The diffusion between steel-cooper is unemployed by pouring molten copper to the heated steel since oxidation occur on steel surface. On the contrary, immersing steel into molten copper could be implemented to make the sandwich material of steel-copper. The bonding of diffusion occur in the layer of steelcopper with highest shear stress of 231.88 $\mathrm{N} / \mathrm{mm}^{2}$. However, the immersing method should be improved to gives a better product since cavities caused by trapped air still exist and reducing the quality of laminates.

\section{ACKNOWLEDGMENT}

The authors are grateful for the research funding of the Ministry of Research, Technology and Higher Education, Indonesia. The authors also wish to thank to the Dean of Faculty of Engineering Yogyakarta State University for using facilities of Material and Processing Laboratory.

\section{REFERENCES}

Al-Qur'an dan Terjemahnya, 2007, Media Insani Publishing, Surakarta, Indonesia.

Bouaziz, O., Drilliet, P., SArtini, J.C., 2006, Metallic Sandwich Sheet, United States Patent, Publication No: US 2006/0147743 Al. (6 July 2006).

Cahyono, G.M.D., 2010, Aplikasi Teknik Pembuatan Keris Pada Komposit Laminate Baja-Nikel, accessed on $5^{\text {th }}$ Janaury 2011 from http://digilib.its.ac.id/ITSUndergraduate-3100010039072/9900. 
Clyne, T.W., and Markaki, A., 2004, Sandwich Material, United States Patent, Patent No: US 6,764,772 B2. (20 July 2004).

Garnault, A.M., and Brouttier, M.F., MultiLayer Metal Sandwich Materials Comprising Epoxy-Based Adhesive Systems, United States Patent, Publication No.: US 2004/0058181 A1. (25 March 2004).

Groll, W.A., Method of Making a Composite Metal Sheet, United States Patent, Patent No: US 7,353,981 B2. (8April 2008).

Nagai, H., Nishihara, M., Thoshiaki, S., MetalResin-Metal Sandwich Laminates,
United States Patent No: 4,594,292. (10 June 1986).

Ostroushko, D., and Mazancová, E., 2010, Chosen Properties of Sandwich CrNi Steel-Ti Material after Explosive Cladding., accessed on $5^{\text {th }}$ January 2011 from http://www.metal2011.com/ data/metal2010/sbornik/lists/papers/336 .pdf;

Pflug, J., and Vangrimde, B., 2003, New Sandwich Material ConceptsContinuously Produced Honeycomb Cores, accessed on $5^{\text {th }}$ January 2011 from http://www.compositesintransport.com/ 